\title{
A quick estimation of the economics of exploration projects - rules of thumb for mine capacity revisited - the input for estimating capital and operating costs
}

\author{
F.- W. Wellmer (1) and M. Drobe ${ }^{(2)}$ \\ (1) Neue Sachlichkeit 32, D-30655 Hannover, Germany. \\ fwellmer@t-online.de (corresponding author) \\ (2) Bundesanstalt für Geowissenschaften und Rohstoffe, D-30655 Hannover, Stilleweg 2, Germany. \\ malte.drobe@bgr.de
}

\begin{abstract}
Despite striving to make the most of the recycling economy, primary raw materials will always be needed. The discovery of these requires primary exploration, which is inherently associated with risks and costs. Nevertheless, by minimizing exploration expenditure, we can increase resource efficiency. One way of ensuring that this is accomplished is to continuously assess the odds of reaching our economic goals during exploration. For this purpose, order of magnitude economic calculations are needed, using rules of thumb. For estimating operating and investment costs, capacities for a putative mine are assumed, always allowing for economies of scale, i.e. the fact that with increasing capacity the operating costs decrease, while the capital costs increase. For estimating both the capacities and the life of a mine, for a given deposit, a rule called “Taylor's Rule", formulated in 1977, is widely applied. In 2009 Long derived a new relationship between reserves and mine capacities, observing that over time, but especially in the last two decades of the last millennium, the international mining industry experienced a trend of increasing mine capacities. He separated open pit and block caving mines with larger capacities from conventional underground mines, which in general have smaller capacities. In this paper, we use our own rules of thumb, to examine what influence these two approaches have on evaluating the economics of a mine, taking the internal rate of return (IRR) as our criterion of economic viability. The upshot in general is that when moving from capacities according to Taylor to capacities according to Long, the economic outcomes of the rules-of-thumb economic evaluations vary significantly. When Long's and Taylor's recommendations were tested with real world examples of active mines, either in production since 2012 or later, or projects at the construction or feasibility stage, we found relatively good agreement between real world data and Long's relationships. Therefore, we recommend that in predictive economic evaluations of projects at the exploration stage Long's method should be used instead of Taylor's Rule. This study shows that due to technological progress the reserve-capacity relationship needs to be periodically re-examined.
\end{abstract}

Keywords: exploration phases, mining design, mining economy, production capacity.

\section{Sobre la estimación rápida de la economía de los proyectos de exploración. Revisión de las reglas generales acerca del dimensionamiento de la capacidad de la mina: los datos de entrada para la estimación de los costes operativos y del capital}

\section{RESUMEN}

A pesar del esfuerzo que significa el máximo aprovechamiento en la economía del reciclaje, las materias primas siempre van a ser necesarias. Por otra parte, su descubrimiento requiere de una etapa de exploración que está inherentemente asociada con los riesgos y los costes. Sin embargo, al minimizar los gastos de exploración, podemos de esta manera aumentar la eficiencia de los recursos. Una forma segura de que esto 
F.-W. Wellmer and M. Drobe, 2019. A quick estimation of the economics of exploration projects... Boletín Geológico y Minero, 130 (1): 7-26

se logre consiste en evaluar continuamente y durante la exploración, las probabilidades de alcanzar nuestras metas económicas. Para este propósito, se necesitan cálculos económicos de orden de magnitud, utilizando reglas generales o aproximadas ("rules of thumb"). Así, para estimar los costos operativos y de inversión, se supone la capacidad de una supuesta explotación, permitiendo siempre el uso de las economías de escala. Un ejemplo es que, con el aumento de la capacidad de producción, los costes operativos por tonelada disminuyan, mientras que los costes de capital aumentan. Para un depósito mineral dado, en la estimación de capacidades y, al mismo tiempo, de la vida útil de una mina, se aplica ampliamente una regla llamada "Regla de Taylor," formulada en 1977. En 2009, Long propuso una nueva relación entre las reservas y las capacidades de extracción minera, observando que, a lo largo del tiempo, pero especialmente en los dos últimos siglos del milenio pasado, la industria minera internacional experimentó una tendencia hacia el aumento de las capacidades de producción. Long separó las minas con explotaciones a cielo abierto y subterráneas con "block caving" (ambas con las mayores capacidades de producción), de las minas subterráneas convencionales que, en general, poseen menores capacidades. En este documento, empleando nuestras propias reglas empíricas, examinamos qué influencia tienen estos dos enfoques en la evaluación de la economía de una mina, tomando la tasa interna de retorno (TIR) como nuestro criterio de viabilidad económica. El resultado general es que, al pasar de las capacidades según Taylor a las capacidades según Long, los resultados de las evaluaciones económicas de las reglas generales varían significativamente. Cuando las recomendaciones de Long y Taylor se probaron con ejemplos reales de minas activas (desde 2012 o más adelante), o bien en proyectos que se encontraban en la etapa de desarrollo o de viabilidad, encontramos un acuerdo relativamente bueno entre los datos del mundo real y las relaciones de Long. Por lo tanto, recomendamos que, en las evaluaciones económicas predictivas de proyectos en la etapa de exploración, se use el método de Long en lugar de la regla de Taylor. El estudio muestra que debido al progreso tecnológico, la relación entre capacidad y reservas debe reexaminarse periódicamente.

Palabras clave: capacidad producción, diseño minero, economía minera, fases exploración.

\section{Introduction}

We are living in a world of accelerating raw material consumption. Let us take as an illustration the mathematical rule that each time a consumption doubles (Table 1), mankind has used as many raw materials in the last period of doubling as in all the times before. Examining this rule, we see accelerating consumption, mainly due to the rapid increase of consumption in China since the turn of the millennium. Although there are no indications that we are facing a disturbance of the dynamic balance between reserves and consumption in the near or medium future (Tilton et al., 2018, Wellmer 2008), the rising consumption calls for measures to increase raw material efficiency as much as possible. Good examples are the efforts within the European Union to improve the circular

\begin{tabular}{|l|l|l|l|}
\hline Commodity & $\begin{array}{c}\text { Production } \\
\mathbf{2 0 1 6}\end{array}$ & $\begin{array}{c}\mathbf{5 0 \%} \text { of } \mathbf{2 0 1 6} \\
\text { production }\end{array}$ & $\begin{array}{c}\text { Years, when } \\
\text { production was } \\
\mathbf{5 0 \%} \text { of } \mathbf{2 0 1 6}\end{array}$ \\
\hline aluminium & 58.7 mio t & 29.4 mio t & $2003 / 2004$ \\
\hline copper & 20.3 mio t & 10.2 mio t & $1995 / 1996$ \\
\hline zinc & 12.8 mio t & 6.4 mio t & $1977 / 1978$ \\
\hline steel & $1,628.6$ mio t & 814.3 mio t & $1999 / 2000$ \\
\hline
\end{tabular}

Table 1. Doubling periods (BGR 2018).

Tabla 1. Períodos de duplicación (BGR 2018). economy, i.e., to increase the share of secondary materials (EC 2018).

Even if the share of secondary raw materials, which were $57 \%$ for aluminium, $43 \%$ for steel or $41 \%$ for copper in 2016 in Germany (BGR 2017), could be increased significantly, primary production is and will still be needed for as long as one can see. This structural requirement more or less follows logically from the concept of the residence time of primary materials in the economy, (Grosse 2011, Wellmer et al., 2018); from the fact that often enough it does not make sense to recycle very complex materials if one wants to minimize energy consumption and $\mathrm{CO}_{2}$-output at the same time, (Steinbach and Wellmer 2010); and, last but not least, the laws of thermodynamics do not permit complete recycling. Consequently, mined out reserves and deposits must be continuously replaced by exploration to maintain a dynamic balance between reserves and production. As a rule of thumb, replacement costs in the mining industry vary between $2 \%$ and $5 \%$ of revenues (e.g., for gold: Mineral Council of Australia 2014).

As an element of resource efficiency, these exploration activities also have to be executed as efficiently as possible. Exploration moves in steps, based on encouraging results, to more and more expensive stages. How difficult from a geophysical point of view it can be to move, for example, from the geophysical investigation stage to the more expensive drilling 
stage was recently discussed by Harvey (2018). One tool for improving exploration efficiency is to continuously have milestones installed for reviews, especially economic reviews. Milestones are decision points to check if the exploration results justify a continuation or cessation of activities depending on the likelihood that the minimum economic objectives can be reached. This is shown in Figure 1: progress of exploration activities against risk and costs with milestones. The further advanced a project is, the more expensive exploration will be, with more detailed drilling, beneficiation tests or even underground exploration and bulk sampling, with milestones at each stage. The way in which the probability that a discovery will become viable increases with progressing exploration is shown in Table 2.

Wellmer et al. (2008) developed a series of rules of thumb for quick economic evaluations at the exploration stage, supported by many case studies and examples. Due to new developments in the relationships between expected tonnages and mine capacity, we re-examine these rules of thumb in this paper. The focus will be to get the best estimate of the capacity of a putative mine, because a good estimate of the capacity is the basis for a good evaluation of investment and operating costs.

\section{Tools for quick economic evaluations at the explo- ration stage}

\section{Character of a prefeasibility study}

The purpose of a feasibility study for a mining project is to justify the financing of the project. A feasibility study, therefore, must be bankable. This is not the goal of a prefeasibility study. The prefeasibility study is a tool, used during the exploration phase, to monitor progress from one exploration stage to the next, preliminary to the feasibility stage. The very first economic evaluation, known as a scoping study, is usually done, when sufficient mineralization has been discovered by drilling to estimate the order of magnitude of grade and tonnage, to have the first metallurgical

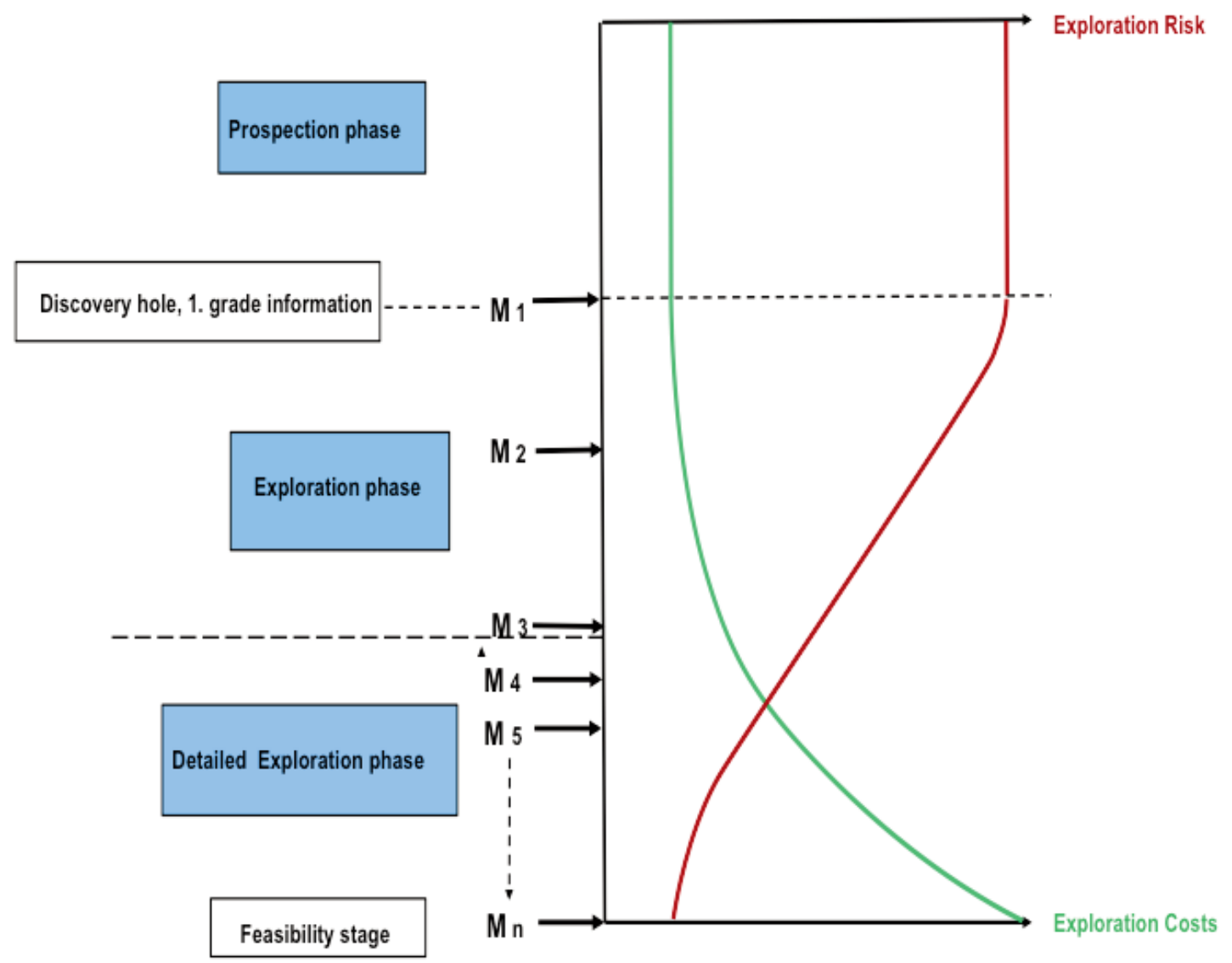

Figure 1. Progress of exploration with milestones, relative risks and relative exploration costs.

Figura 1. Progreso de la exploración con los hitos de $M_{1}$ a $M_{n}$, riesgos relativos y costes relativos de exploración. 


\begin{tabular}{|c|c|c|c|c|c|c|}
\hline 1. & 2. & 3. & 4. & 5. & 6. & 7. \\
\hline 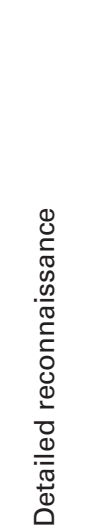 & 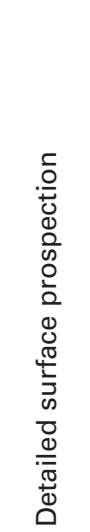 & 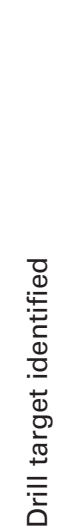 & 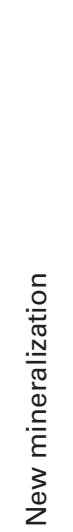 & 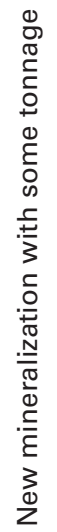 & 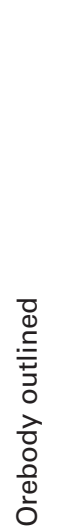 & 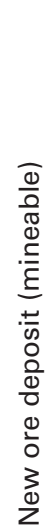 \\
\hline $1: 800$ & $1: 700$ & $1: 90$ & $1: 16$ & $1: 3$ & $1: 2$ & $1: 1$ \\
\hline
\end{tabular}

Table 2. Probability of an exploration project becoming a profitable mine in the second half of the $20^{\text {th }}$ century (Sames and Wellmer 1981).

Tabla 2. Probabilidad de que un proyecto de exploración se convierta en una mina rentable en la segunda mitad del siglo $X X$ (Sames y Wellmer1981). tests done and to estimate the minimum size required for the deposit to be economic.

The general flow sheet for a prefeasibility study is shown in Figure 2 (Wellmer et al., 2008, p.61). In Wellmer et al. 2008, all the modules such as calculations of the revenues via net smelter return are explained with examples. This flow sheet also broadly describes the feasibility study. A feasibility study however is far more detailed and elaborated. It must discuss in detail the justification for metal prices and costs assumed. A feasibility study should also include a sensitivity analysis, showing how price and cost variations influence the economics of the project. Environmental and socio-economic aspects have to be scrutinized in detail as well. The capacity has to be re-examined to see if it is really the best capacity to generate the optimum return on invested capital.

For a feasibility study costs and revenues have to be researched $a b$ ovo, i.e., one has to have quotes for the investment items, from manufacturers for equipment or bids from contractors for a shaft for example. One

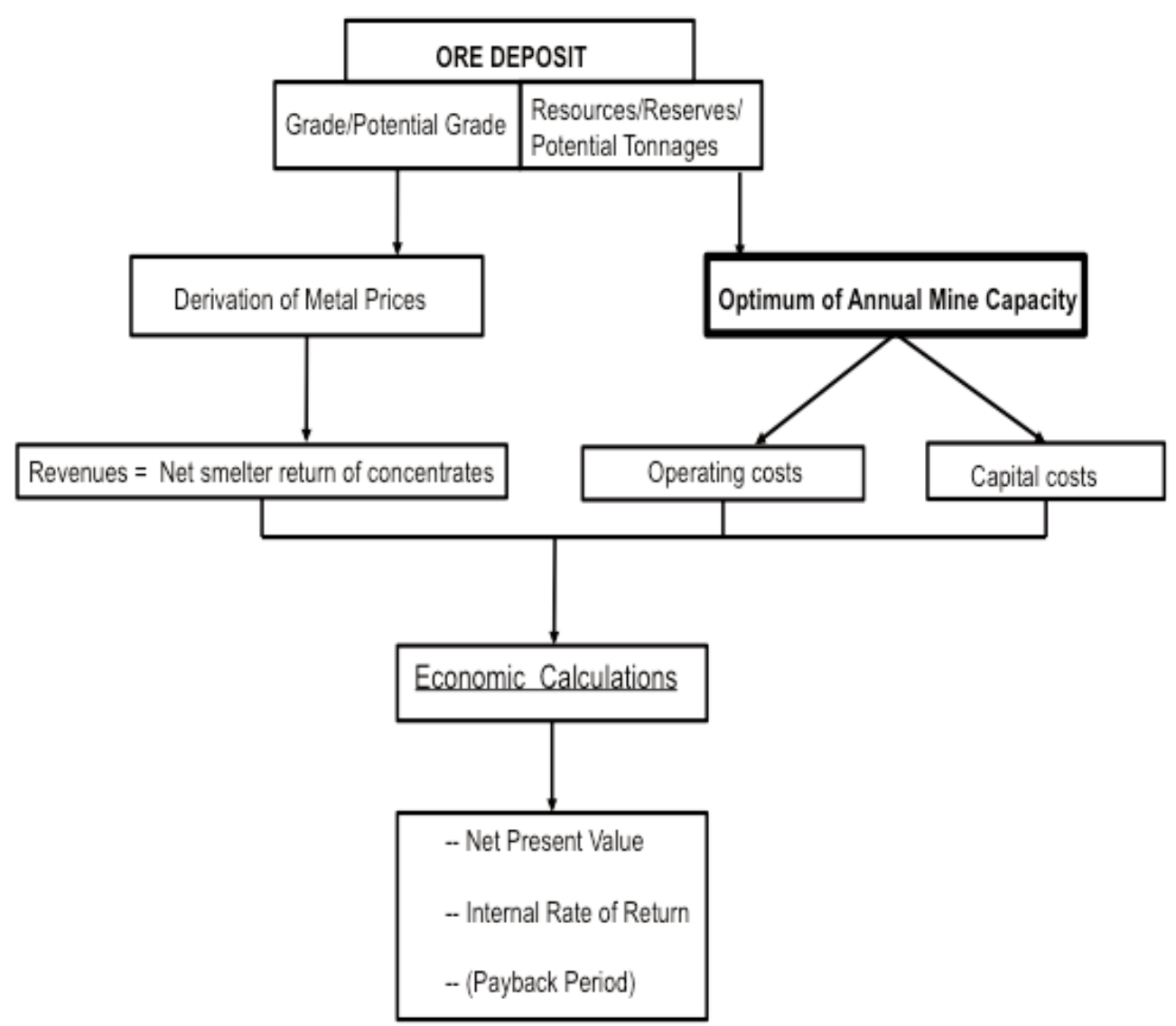

Figure 2. Flow-sheet of a feasibility study for economic evaluations in exploration. The position of the capacity determination, which is critical for determining the investment and operating costs, is highlighted (Wellmer et al., 2008).

Figura 2. Diagrama de flujo de un estudio de viabilidad para evaluaciones económicas en exploración. Se destaca la posición de la determinación de la capacidad de producción que resulta crítica para determinar la inversión y los costes operativos (Wellmer et al. 2008). 
has to have a letter of intent from a smelter or a customer that details under what conditions and at what prices they are willing to buy the product of the future mine. Operating costs have to be developed $a b$ ovo as well on the basis of wage rates, average productivity, bids for fuel, explosives etc. This is a team task. However, any exploration geologist should be able to do a much simpler prefeasibility study based on analogue costs, taken from mines of similar deposits, scaled to the appropriate capacity.

\section{Economic valuation criteria}

Today it has become standard procedure to evaluate an exploration or mining project using dynamic evaluation methods (Wellmer et al., 2008, p. 126 ff). With these methods the discounted cash flows are compared with the amount of investment. Cash flow is the net amount of cash moving in and out of a business, in our case a mining operation, i.e., only true flows of money, the difference between revenues and expenditures such as operating costs, interest, royalties, taxes, but not depreciation which is an accounting concept used to calculate the tax base. Dynamic means that the time value of money is taken for comparison. The time value of money takes into account that money can earn interest over time. A dollar today is worth more than a dollar in a year's time.

As an example, let us assume an interest rate of $5 \%$. Then $\$ 100$ in a saving account would have a value of $\$ 105$ in one year. Argued the other way around, with an interest rate of $5 \%$ you have to have $\$ 105$ in one year to have a present value of $\$ 100$. This means you have to discount future monetary streams or cash flows. This is the reverse formula for compound interest. The discounting factors are, given $(1+i)=q$.

$$
\frac{1}{(1+i)^{n}}=(1+i)^{-n}=q^{-n}
$$

Hereby, $i$ is the chosen interest rate and $n$ the number of years.

For evaluating a mining project and comparing different projects, two methods are commonly used: the net present value method (NPV) and the internal rate of return method (IRR). Given an interest rate, $\mathrm{i}$ and letting $C F_{n}$ denote the cash flow at time $n$, the net present value at time $N$ is:

$$
N P V(N)=\sum_{n=1}^{N}\left(C F_{n} \times q_{j}^{-n}\right)-l
$$

where $N$ is the entire period of $n$ years for which the net present value is calculated and $j$ is a specific year. The $N P V(N)$ (in the following denoted as NPV) is the sum of all net cash flows $\left(C F_{n}\right)$ discounted at a predefined interest rate minus the initial investment $I$ (Equation (2)). The IRR is the interest rate for which the discounted net cash flows equal the investment, $I$, i.e., in Equation (2) the NPV then equals zero.

$$
\sum_{n=1}^{N}\left(C F_{n} \times q_{j}^{-n}\right)=l
$$

A third method is the calculation of the payback period. The payback period is the number of years it takes to pay back the investment from the net cash flow. Normally the undiscounted cash flows are taken. Therefore, this calculation has to be considered as a static, not dynamic method.

\section{Rules of thumb for finding operating and investment costs}

We commented previously that any exploration geologist should be able to execute a prefeasibility study based on analogue costs, taken from similar mines or deposits, up- or downscaled to the appropriate capacity. For up- and downscaling, economics of scale need to be taken into account: the specific operating and investment costs/t decrease with the size of a mine. For investment costs it is observed that the total investment costs increase at a lower rate than the capacity.

Mathematically the economics of scale are taken into account by a power curve relationship:

$$
y=a c p^{b}
$$

Where $a$ and $b$ are coefficients, $y$ stands for the specific or absolute operating or investment costs and $c p$ is the mine capacity.

One example of this power curve rule is the wellknown 0.6 rule of thumb for capital costs $c p$, which says that by increasing the capacity, the absolute investment costs $/$ do not increase at the same ratio but only at the power of 0.6 (in equation 4 then $b=0.6$ ) (Mular 1978, O'Hara 1980, Wellmer et al., 2008, p.99). For example, if capacity doubles, the capital costs would only increase by the factor of 1.5 .

$$
\frac{I_{1}}{I_{2}}=\left(\frac{c p_{1}}{c p_{2}}\right)^{0.6}
$$


For operating costs $O C$ as an example a graph is given in Figure $3 a$ for lead-zinc underground mines and for open-pit copper mines and in Figure 3b. The equation (4) in the case for underground lead-zinc mines is:

$$
O C=7,404 c p^{-0.59}
$$

i.e. the coefficients are: $a=7,404, b=-0.59$.

For open-pit copper mines the equation is:

$$
O C=2,068 c p^{-0.48}
$$

and the coefficients are: $a=2,068$ and $b=-0.48$.

$R^{2}$ in Figure 3 is the coefficient of determination. It is a measure of the degree of correlation (Wellmer et al., 2008, p. 45). It indicates what percentage of the distribution of the data in Figure 3 can be explained by the formula (6 and 7). $R^{2}=0.7404$ in Figure 3a means $74 \%$ of the variation is explained by the formula.

The following is another example to illustrate the effect of economics of scale using the cost curve for underground lead-zinc mines in Figure 3a. The operating costs $O C$ for a 2,000t/day operation would according to formula (6) be: $y=O C=97$ US $\$ /$, practically 100 US $\$ / t$, but for a 10,000 t/day operation the
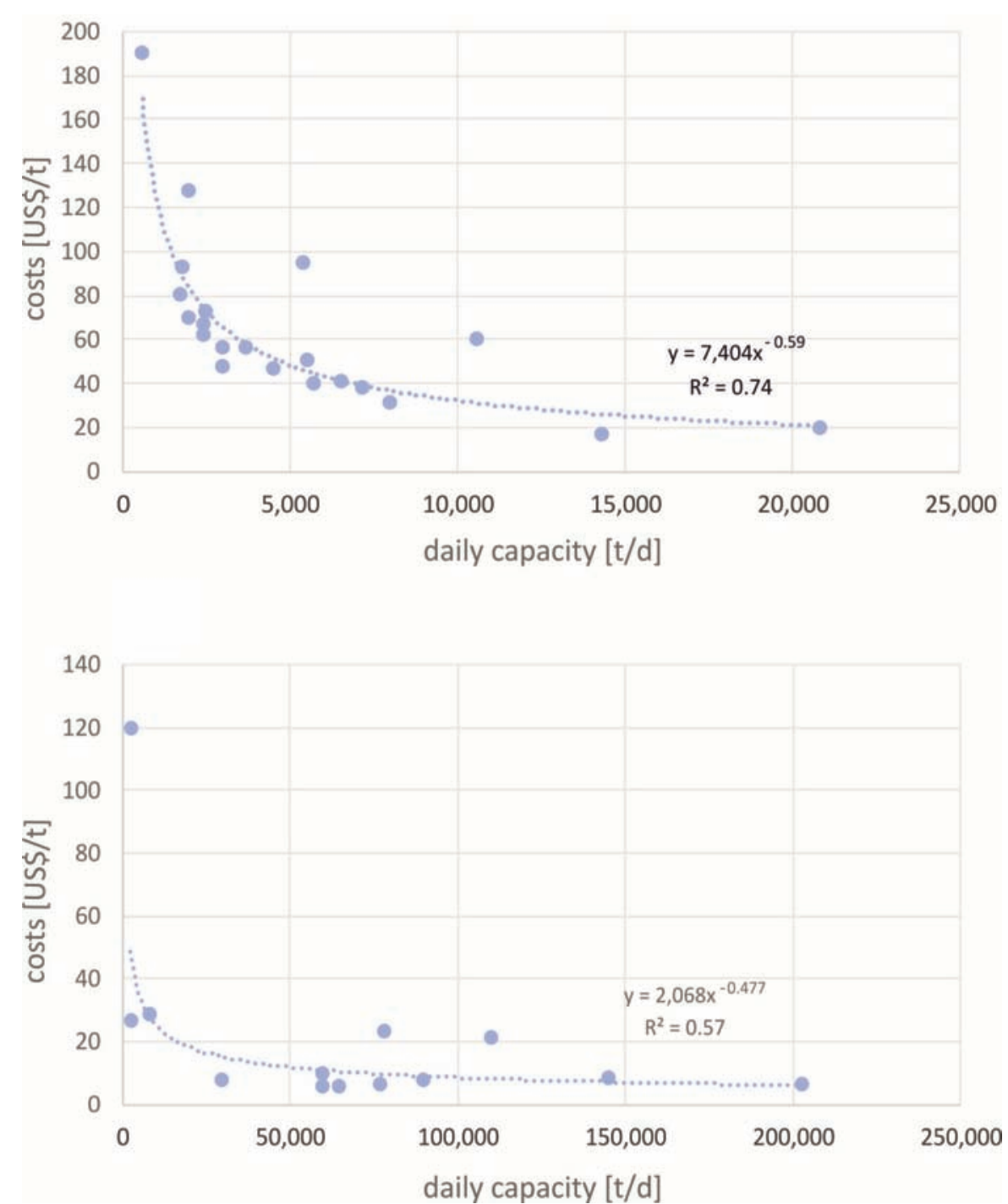

Figure 3. Operating costs $O C$ as a function of daily production capacity $c p$ (BGR 2018). For underground lead-zinc-mines (top). For openpit copper mines (without heap-leach operations) (bottom).

Figura 3. Costos de operación OC en función de la capacidad de producción diaria cp (BGR 2018). Para minas subterráneas de plomo-zinc (arriba). Para minas de cobre a cielo abierto (sin operaciones de lixiviación en pilas) (abajo). 
operating cost $O C$ would only be $O C=39 U S \$ / t$, practically 40 US $\$ / t$ (because we calculate only with round numbers in a simple rule-of-thumb calculation).

Q.E.D. It hardly needs emphasizing how important it is to have a good estimate of mine capacity for a prefeasibility study.

\section{Examination of various methods to estimate the opti- mum capacity of a mine}

Normal procedure in mine planning would be to find solutions which maximize NPV. These are the assumptions for algorithms using methods of operation research and linear programming (Newman et al., 2010, Wellmer and Scholz 2018). Practitioners have found that there are practical limitations and these goals can only seldom be achieved. Lassere (1985) studied elasticity for capacities in relation to reserves and found that these varied from 0.58 to 0.7715 in 15 Canadian mines.

In 1977, an experienced Canadian mining engineer, Hugh Taylor, proposed a rule of thumb for mine capacities based on a sample of about 30 mines. He found that mine capacities increased at three quarters of the increase of reserves (equation 8) (Taylor 1977, 1986). Taking again $x$ as the mine capacity, Taylor's equation is:

$$
\text { tons }_{\text {day }}=c p_{\text {Taylor }}=0.014 \times \text { res }_{\text {exp }}^{0.75}
$$

where tons $s_{d a y}$ are the daily capacity $c p$ and $r e s_{\text {exp }}$ the expected reserves, originally in short tons, however the formula can also be applied using metric tonnes. $\mathrm{He}$ did not distinguish between underground and open-pit mines. Taylor argued that reserves are a three-dimensional volume function, but the sustainable rate of extraction depends on the available working area, which is two-dimensional.

Taylor's rule, as it came to be known, was examined by Wellmer $(1979,1981)$ and McSpadden and Schaap (1984) whose results were in general agreement with Taylor, albeit with certain deviations due to special conditions. Wellmer $(1979,1981)$ examined Canadian base-metal mines at the stage of investment decision, McSpadden and Schaap (1984) porphyry copper deposits worldwide. The US Geological Survey (USGS) has investigated the use of Taylor's rule for open-pit gold-silver and open-pit copper mining and heap-leach operations in the US and underground mining operations of massive sulphide deposits globally (Singer, Menzie and Long 1998, Long and Singer 2001). Whereas these studies were done on a limited number of cases, Long $(2009,2016)$ investigated a much larger sample of mines: 796 open-pit/ block caving and 400 underground mines. (Herein we will use the abbreviation ug for underground mines and op for open-pit and block caving mines.). Although block caving is an underground mining method, Long $(2009,2016)$ included them in the open-pit category, because it is a mass mining method more similar to open-pit methods than other underground methods.

Long's relationships between expected reserves and capacity $c p$ are:

Open-pit and block caving:

$$
\text { tonnes }_{\text {day }}=c p_{\text {Long op }}=0.123 \times r e s_{\text {exp }}^{0.65}
$$

Underground:

$$
\text { tonnes }_{\text {day }}=c p_{\text {Long ug }}=0.297 \times r e s_{\exp }^{0.56}
$$

In Figures 4 and 5 the relationships between Taylor's rule (equation 8) and Long's (equations 9 and 10) are displayed. One can see that the relationship for open-pit and block caving of Long $(2009,2016)$ always requires larger capacities than Taylor's rule would suggest, whereas for underground mines up to an expected reserve of about 10 mio $t$ (exactly 9.6 mio t) Long's relationship returns a larger capacity than Taylor, and above 10 mio t for a smaller capacity (Fig. $5 b)$. Figure 5a shows the ratio between Long (openpit, block caving) and Taylor and between Long (underground) and Taylor, Figure $5 \mathrm{~b}$ enlarged for the steeper part of the curves up to a capacity of 50 mio $t$. It is obvious that beyond expected reserves of 50 mio $t$ the ratio for open-pit/ block caving approaches a value of 1.1 and for underground mines of 0.4 (Fig. 5a). The values of Taylor's and Long's capacities are given in Table 3, the ratios between Long's and Taylor's value in Table 4.

An explanation as to why Long's relationship for open-pit/block caving mines (Long 2009) yields larger capacities than Taylor's rule (Taylor 1977, 1986) can be found in Crowson (2003). He studied copper mines worldwide and found that capacities relative to reserves grew from 1980 onward, but especially in the 


\section{Daily Capacity}

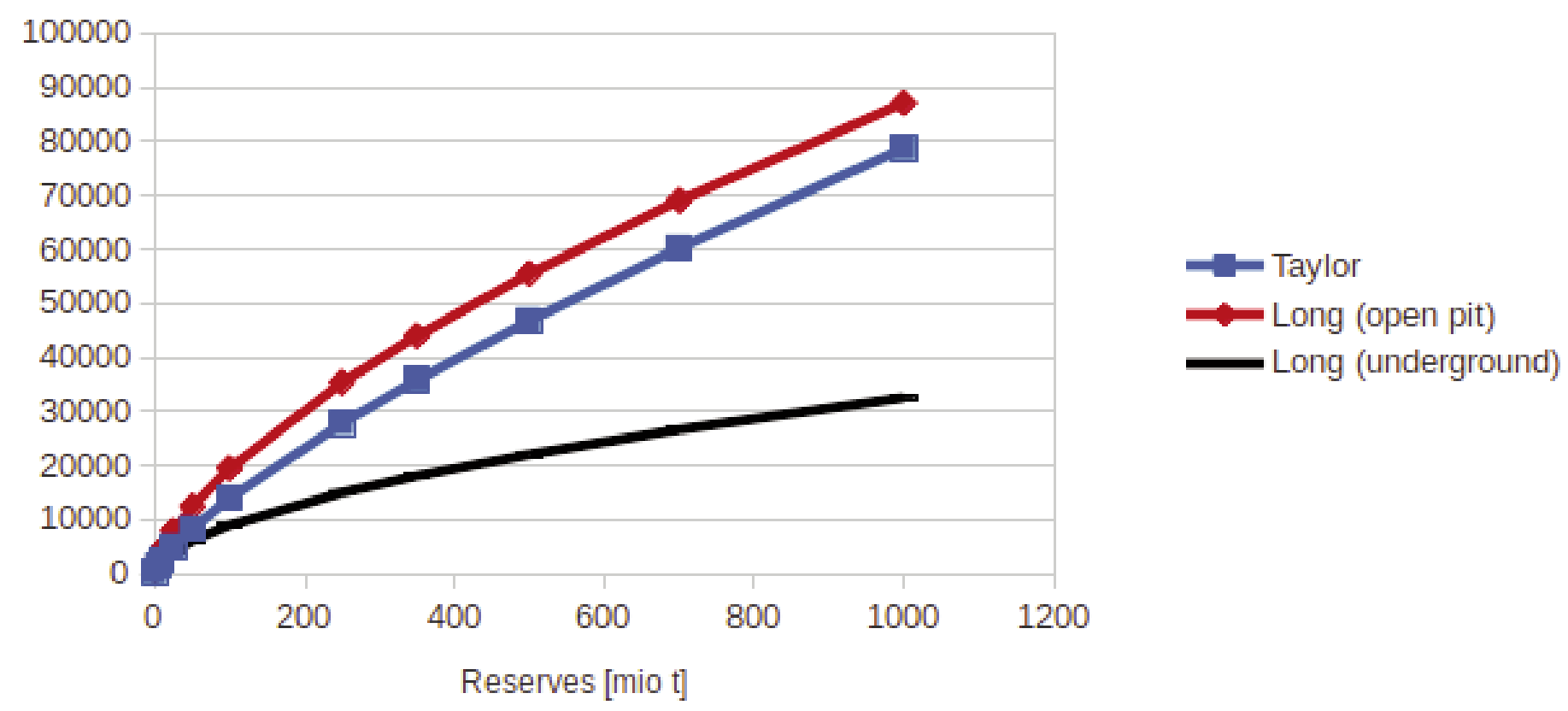

Figure 4. Taylor's and Long's relationships between reserves and capacity.

Figura 4. Relaciones de Taylor y de Long entre reservas y capacidad.
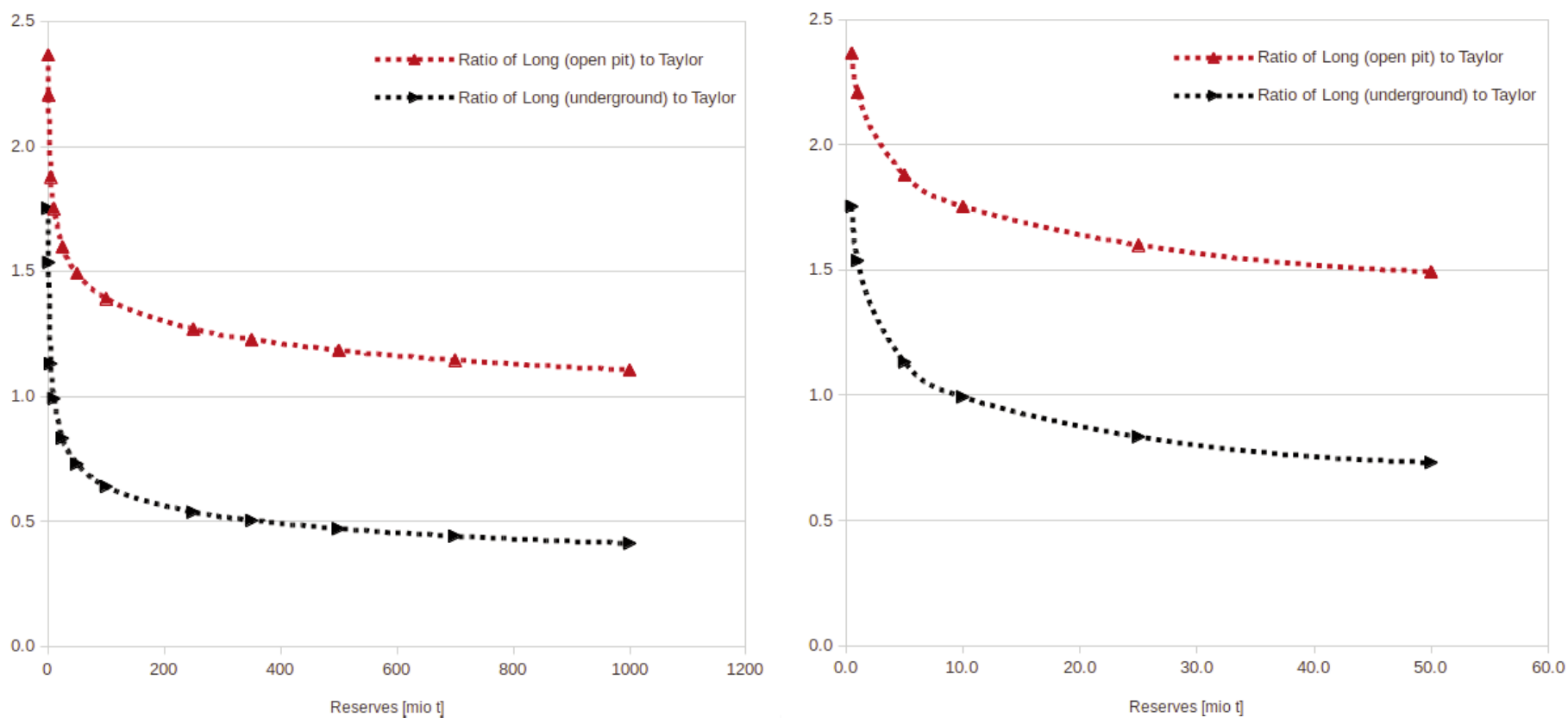

Figure 5. Ratios between Long's relationships for open-pit/block caving and underground mines and Taylor's rule. Left: for the range of reserves to $1,000,000,000$ t. Right: for a range of reserves only to $50,000,000 t$.

Figura 5. Ratios entre las relaciones de Long y la regla de Taylor para minas "a cielo abierto"/"block caving"subt. y minas subterráneas. Izquierda: Para el rango de reservas a 1000000000 de toneladas. Derecha: Para un rango de reservas solo a 50000000 toneladas. 
F.-W. Wellmer and M. Drobe, 2019. A quick estimation of the economics of exploration projects... Boletín Geológico y Minero, 130 (1): 7-26

\begin{tabular}{|l|l|l|l|l|l|l|}
\hline $\begin{array}{c}\text { Expected } \\
\text { reserves } \\
\text { (in mio t) }\end{array}$ & \multicolumn{1}{|c|}{\begin{tabular}{c} 
Taylor's rule \\
\hline 0.1
\end{tabular}} & \multicolumn{1}{|c|}{$\begin{array}{c}\text { Taylor's rule: } \\
\text { range }\end{array}$} & $\begin{array}{c}\text { Long: open-pit + } \\
\text { block caving }\end{array}$ & $\begin{array}{c}\text { Long: } \\
\text { open pit, block + } \\
\text { caving: range }\end{array}$ & $\begin{array}{c}\text { Long: } \\
\text { Long: under- } \\
\text { ground }\end{array}$ & $\begin{array}{c}\text { underground: } \\
\text { range }\end{array}$ \\
\hline 0.5 & 80 & $65-100$ & 220 & $200-250$ & 180 & $150-200$ \\
\hline 1.0 & 260 & $250-300$ & 620 & $600-700$ & 460 & $450-500$ \\
\hline 5 & 450 & $400-500$ & 980 & $900-1,000$ & 680 & $650-750$ \\
\hline 10 & 1,500 & $1,250-1,800$ & 2,800 & $2,700-2,900$ & 1,700 & $1,600-1,800$ \\
\hline 25 & 2,500 & $2,100-3,000$ & 4,400 & $4,300-4,500$ & 2,500 & $2,400-2,600$ \\
\hline 50 & 5,000 & $4,200-6,000$ & 8,000 & $7,900-8,100$ & 4,100 & $4,000-4,300$ \\
\hline 100 & 8,400 & $7,000-10,000$ & 12,400 & $12,300-12,500$ & 6,100 & $6,000-6,200$ \\
\hline 250 & 14,000 & $11,500-17,000$ & 19,500 & $18,000-21,000$ & 9,000 & $7,500-10,000$ \\
\hline 350 & 27,500 & $23,000-32,500$ & 35,000 & $33,000-37,000$ & 15,000 & $13,500-16,500$ \\
\hline 500 & 35,000 & $30,000-42,000$ & 44,000 & $42,000-46,000$ & 18,000 & $16,500-20,000$ \\
\hline 700 & 46,000 & $39,000-55,000$ & 55,000 & $53,000-57,000$ & 22,000 & $20,000-24,000$ \\
\hline 1,000 & 60,000 & $50,000-72,000$ & 70,000 & $68,000-72,000$ & 27,000 & \\
\hline
\end{tabular}

Table 3. Suggested mine capacities cp (daily production, tonnes/day) by Taylor (1977) and Long (2009). Ranges: Taylor (1986), for Long estimates by authors.

Tabla 3. Capacidad de mina sugerida cp (producción diaria, toneladas/día) porTaylor (1977) y Long (2009). Rangos: Taylor (1986), para estimaciones de Long por los autores.

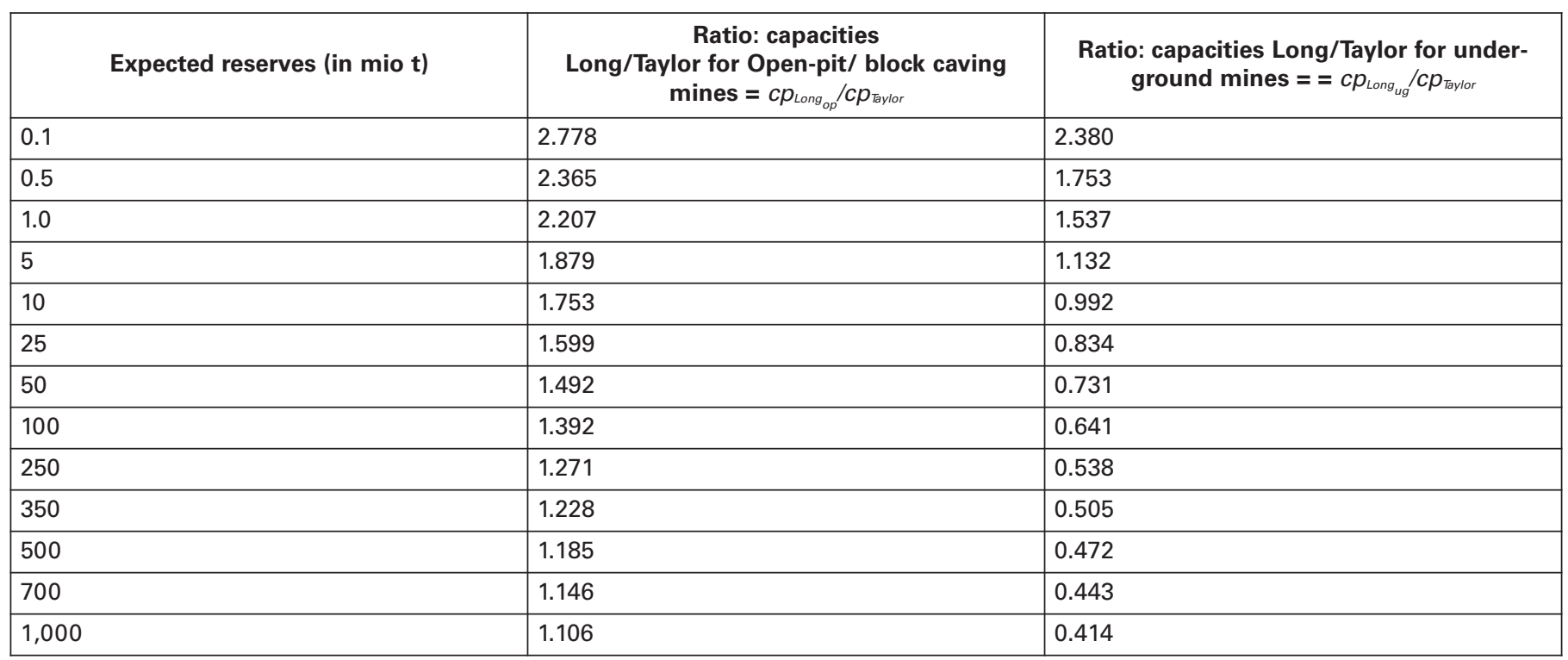

Table 4. Ratio of capacities, $c p_{\text {Long }} / c p_{\text {Taylor, }}$ comparing Taylor's rule with Long's relationships.

Tabla 4. Ratio sobre capacidades, $c p_{\text {Long }} / c p_{\text {Taylor, }}$ comparando las relaciones de Taylor con las de Long.

1990s. This is exactly the time difference between Taylor's and Long's studies. Due to depressed commodity prices, mines were forced to radically reduce the costs per unit commodity sold (e.g. Mount Isa Mines 2001, graph in Wellmer et al., 2008, Fig. 6.3a). One way to cope was to increase capacity to be able to take advantage of the economics of scale (Humphreys 2001). For his study concerning capaci- ties, Crowson (2003) did not distinguish between open-pit and underground mines.

Whereas this is a convincing explanation for large tonnage bulk mining operations, such as open-pit mines or block caving operations, an explanation for the discrepancy with respect to underground mines is more difficult. As a matter of principle due to space constraints, it is easier to enlarge the operating area 
of an open pit, than of an underground mine. Perhaps operations with expected reserves of less than 10 mio $t$, i.e., of daily capacities below between 2100 and $3000 \mathrm{t}$ (Wellmer et al, 2008, p.81), tried to achieve lower operating costs by larger capacities (economies of scale), but mines with larger orebodies, being more flexible, raised the cut-off grade instead and mined more selectively, in effect reducing output. This could under favourable circumstances result in stretching the lifetime of the mine, thereby increasing the chances of weathering the downturn and surviving until higher metal prices returned, to offset losses or low earnings of the past.

Another explanation would be that the larger capacities below 10 mio t reserves are an artifact due to the limited amount of data of Taylor (Long 2018). The senior author of this paper has often found that when using power curve relationships the steeper part of the curves, i.e. at low $x$-values, the $y$-values could change significantly, if the $x$-values change slightly. In Section 5, we examine the trends in underground mining since 2012. For underground mines, we find that the actual mine capacities for reserves of up to 25 mio $t$ are not only larger than the ones postulated by Taylor's rule, but also larger than those postulated by Long (equation 16). This translates into shorter lifetimes.

Such short lifetimes require special conditions for a profitable mining operation: satellite orebodies in a well- known mining camp like the gold mining camp of Kalgoorlie in Western Australia, enabling it to use existing infrastructures such as beneficiation plants

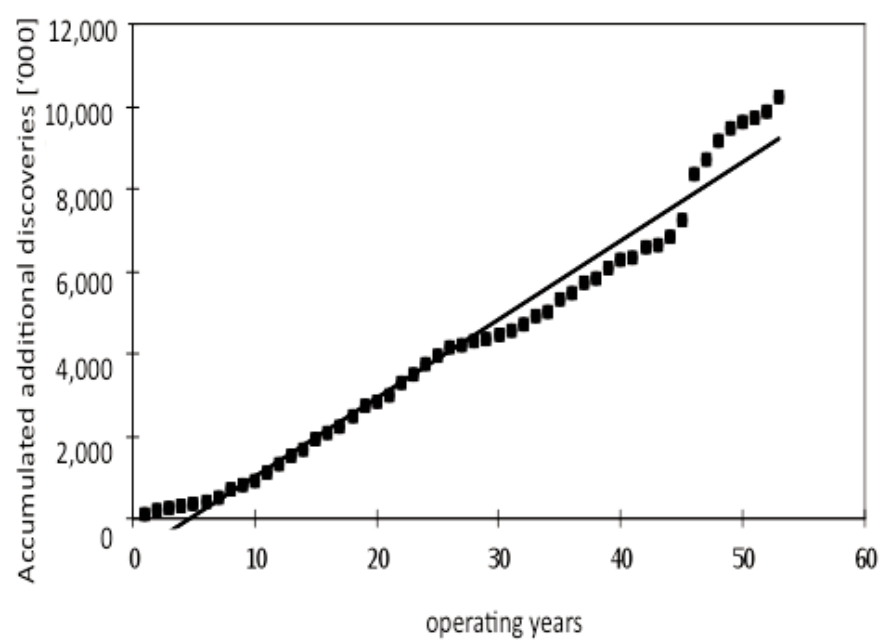

Figure 6. Reserve growth of the Norseman gold vein deposit, Western Australia (Wagner, 1999).

Figura 6. Crecimiento de las reservas del depósito filoniano de oro Norseman/Western Australia (Wagner, 1999). (e.g. Glasson et. al., 1988). Another example are vein mining operations, which frequently operate with low defined reserves, being confident from experience that by continuous exploration parallel to exploitation the reserve/production ratio can be kept more or less constant-a good example of the so-called reserve growth (Wellmer 2008). One often observes that these vein mines, such as ones for gold, barite or fluorite, work with reserves ahead of about 5 years (e.g. Johnson 1988 for gold vein deposits in Norseman, Australia, Nelles 2018, Podufal 2018 for barite and fluorite mines in Germany). Figure 6 shows the gold vein deposit in Norseman, Australia, as an example of a constant reserve growth over more than 50 years. This puts into question the validity of the capacity and lifetime formulas for small ore bodies.

\section{Economic evaluations of the differences between Taylor's (1986) and Long's (2009) equations.}

\section{Background}

We will now attempt to assess how the changes in capacity going from Taylor's rule to Long's relationships influence economic parameters, using internal rate of return IRR (Fig. 2) as an economic yardstick. We will work with rules of thumb and rules of experience which are appropriate to the phase of exploration, i.e. at an early stage of an economic appraisal (Wellmer et al., 2008). To estimate the significance of the differences between Taylor's rule (equation 8) and Long's relationships (equations 9 and 10) in economic terms we have to take into account two counter-acting effects: with increasing capacity operating costs will decrease, but absolute investment costs will increase and vice versa.

To reappraise the effect of capacity changes from Taylor's rule to Long's relationships, we will use a rule of thumb that for economically attractive mining projects the ratio between investment $I$ and cash flow $C F$ (cash flow before interest, taxes and royalties) should be around 3 (Wellmer et al., 2008, p. 143, Götz 2012). This is a rough and ready calculation to estimate if a project is of economic interest:

$$
\frac{I}{C F} \approx 3
$$

For constant annual cash flows $/ / C F$ equals the annuity present value factor (Wellmer et al., 2008, p. $226,227)$, from which the internal rate of return IRR can be calculated (equation 3 ). The derivation is given 
in Appendix 1. An $I / C F$ value of 3 is equivalent to an IRR of $31.1 \%$ for an operating period of $n=10$ years, and to an IRR of $33.2 \%$ for an operating period of $\mathrm{n}=20$ years.

We will not calculate absolute values but consider only ratios between Taylor's and Long's relationships for identical reserves and examine what effect a switch from Taylor to Long has on the economics of a project, and then apply the 0.6 rule for investment costs (equation 5).

The ratios for open-pit and underground mines are as follows:

- For open-pit mines:

The ratio for investment cost is:

$$
\frac{I_{\text {Long op }}}{I_{\text {Taylor }}}=\left(\frac{c p_{\text {Long op }}}{c p_{\text {Taylor }}}\right)^{0.6}
$$

The ratio for cash flow is:

$$
\frac{C F_{\text {Long op }}}{C F_{\text {Taylor }}}=\frac{\left(2 \times c p_{\text {Taylor }}^{-0.48}-c p_{\text {Long op }}^{-0.48}\right) \times c p_{\text {Long op }}}{c p_{\text {Taylor }}^{0.052}}
$$

- For underground mines:

The ratio for investment costs is:

$$
\frac{I_{\text {Long ug }}}{I_{\text {Taylor }}}=\left(\frac{c p_{\text {Long ug }}}{c p_{\text {Taylor }}}\right)^{0.6}
$$

The ratio for cash flow is:

$$
\frac{C F_{\text {Long ug }}}{C F_{\text {Taylor }}}=\frac{\left(2 \times c p_{\text {Taylor }}^{-0.59}-c p_{\text {Long ug }}^{-0.59}\right) \times c p_{\text {Long ug }}}{\mathrm{cp}_{\text {Taylor }}^{0.41}}
$$

The derivations of equations (12 to 15 ) are given in Appendix 2. The capacities $c p$ are given in Table 3, the ratios in Table 4.

Because we want to examine changes in the economics of projects with either Taylor's or Long's capacities using the ratio between investment $I$ and cash flow CF (equation 11), we can combine equa- tions 12 and 13, resp. 14 and 15 . Thus the equations for relative changes in economics are:

open pit:

$$
r_{\text {econ }}=\frac{\frac{I_{\text {Long op }}}{I_{\text {Taylor }}}}{\frac{C F_{\text {Long op }}}{C F_{\text {Taylor }}}}
$$

underground:

$$
r_{\text {econ }_{\text {ug }}}=\frac{\frac{I_{\text {Long ug }}}{I_{\text {Taylor }}}}{\frac{C F_{\text {Long ug }}}{C F_{\text {Taylor }}}}
$$

\section{Evaluation for open-pit/block caving mines}

In equations (12) and (13) we compare ratios for investment costs $I$ and cash flow CF for different capacities based on Taylor's and Long's relationships for open-pit and block caving mines. In order to examine the influence of either choice on mine economics, i.e. the annuity present value factors, using the rule of thumb of equation (11)

$$
\frac{I}{C F} \approx 3
$$

we have to multiply the ratios given in equations (16) and (17) by 3 . These values are the annuity present value factors and are given in Table 5 and 6 . For orientation, a graph of the annuity present value factors as a function of operating years $n$ (up to 20 years) and the factor $q=1+i$, where $i$ is the interest rate (see equation 1) is given in Figure 7. This would be the internal rate of return of a project before interest, taxes and royalties.

$$
\begin{aligned}
& b_{n_{o p}}=r_{e c o n_{o p}} \times 3 \\
& b_{n_{u g}}=r_{e c o n_{u g}} \times 3
\end{aligned}
$$

As can be seen in Figure 4, Figure 5a and Table 4, the capacities of Long are always larger than the capacities ofTaylor. The economics of open-pit mining clearly benefit from economies of scale. The ratios of I/CF in Table 5 are always smaller than 3, our base case, thereby improving the IRR economics to values 


\begin{tabular}{|l|l|l|l|}
\hline $\begin{array}{c}\text { Expected } \\
\text { reserves } \\
\text { (in mio t) }\end{array}$ & $\begin{array}{c}\text { Lifetime } \\
\text { according to } \\
\text { Long's formu- } \\
\text { la for capacity } \\
\text { (9) in years }\end{array}$ & $\quad / / C F=\boldsymbol{b}_{n_{o p}}$ & $\begin{array}{c}\text { Interest rate } \mathbf{~} \\
\text { of the annuity } \\
\text { present value } \\
\text { factor } \boldsymbol{b}_{n_{o p}}\end{array}$ \\
\hline 0.5 & 2.3 & 1.6 & 24.7 \\
\hline 1.0 & 3 & 1.7 & 34.8 \\
\hline 5 & 5 & 1.8 & 47.6 \\
\hline 10 & 6.5 & 1.9 & 48.5 \\
\hline 25 & 9 & 2.1 & 46.0 \\
\hline 50 & 11.5 & 2.2 & 44.8 \\
\hline 100 & 14.5 & 2.3 & 43.2 \\
\hline 250 & 20 & 2.5 & 40.0 \\
\hline 350 & 23 & 2.5 & 40.0 \\
\hline 500 & 26 & 2.6 & 38.5 \\
\hline 700 & 29 & 2.7 & 37.0 \\
\hline 1,000 & 33 & 2.8 & 35.7 \\
\hline
\end{tabular}

Table 5. Changes in economics from using Long's instead of Taylor's capacities for open-pit mines.

Tabla 5. Cambios en la economía por el empleo de las capacidades obtenidas por la relación de Long en lugar de las de Taylor para minas a cielo abierto. better than $30 \%$ (Fig. 7). Fig. 5a shows that the ratio between the capacities of Long/Taylor approaches the value of 1 for higher capacities, and the value of $I / C F$ approach the value of 3 as expected (Table 5). To determine the interest rate of the annuity present value factor the lifetime of the mine also has to be considered. Table 5 shows that the difference in economics of operation peaks at 10 mio $t$ expected reserves.

\section{Evaluation for underground mines}

As can be seen in Figure $5 \mathrm{~b}$ and Table 2 the ratio of capacities for Taylor and for Long is about 1 for reserves of 10 mio t. Therefore the ratio of $I / C F=3$, as our base case is realized for reserves of 10 mio t only. For smaller reserves, Long's capacities are higher than Taylor's, thereby benefitting from economies of scale, i.e. the ratio I/CF improves. For reserves larger than 10 mio $t$, Long's capacities are smaller, meaning a loss of economies of scale. This has the consequence of $/ / C F$-ratios higher than 3 , i.e. a lower IRR. To

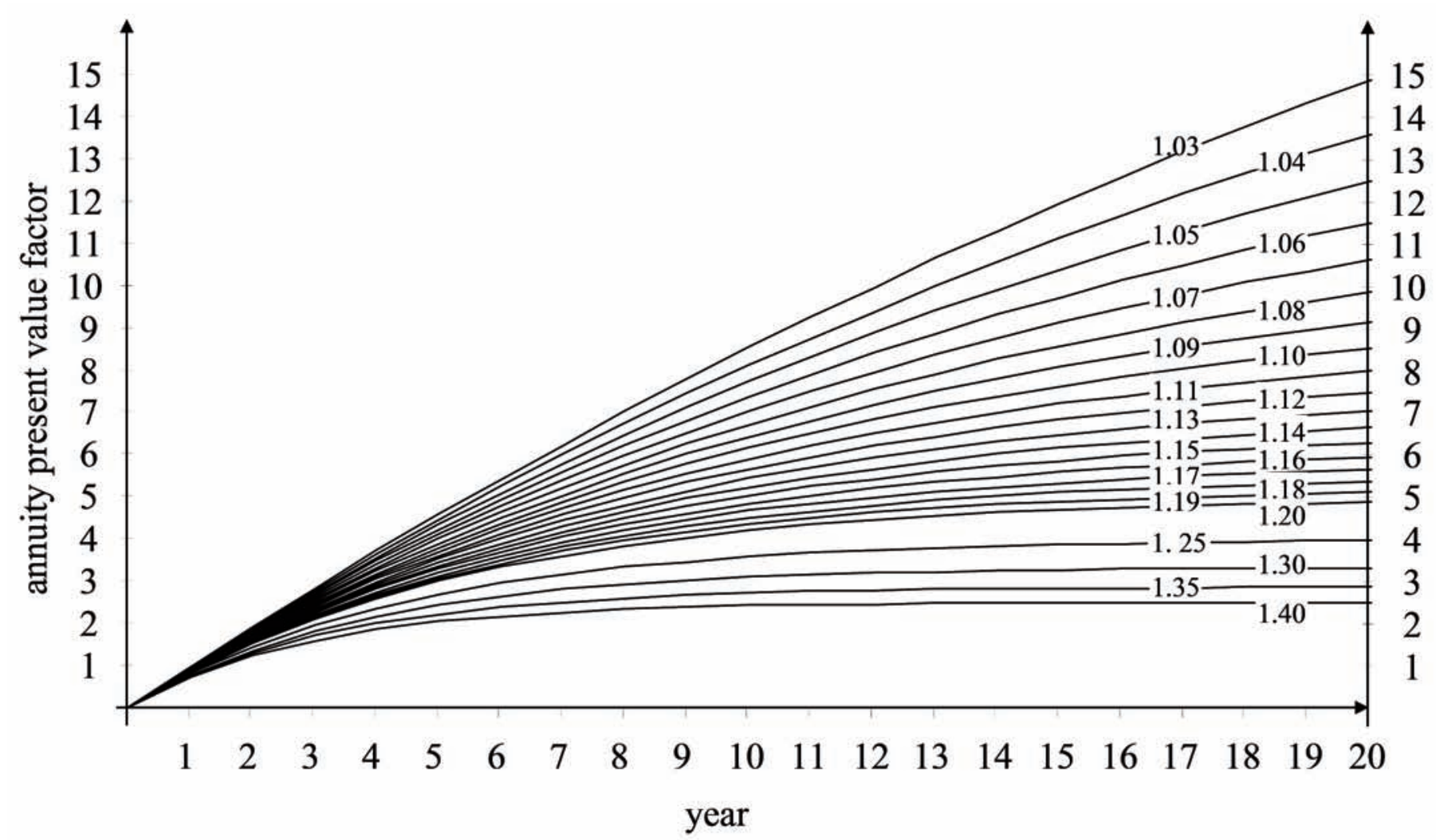

Figure 7. Annuity present value factors $b_{n}$.

Figura 7. Factores del valor actual anual $b_{n}$. 
determine the interest rate of the annuity present value factor, the lifetime of the mine also has to be considered. The results shown in Table 6 indicate that the optimum economic returns are achieved at expected reserves of 5 mio t. Since the discrepancy between Taylor's and Long's capacities increases with increasing reserves, the annuity present value factor increases, i.e., the project economics become worse and worse, the higher the tonnage of the expected reserves become (Fig. 7). To place these interests rated in context, an investor today would expect an IRR of $15 \%$ for a project after accounting for interest, royalties and taxes (Gleeson 2017).

Finally, it is noted again that these are model calculations to illustrate the effect of capacity changes using Long's relationships instead of Taylor's formula. For real life cases the concrete economic results might be quite different.

\section{Comparison of real data since 2012 with the relation- ship of Long (2009) and Taylor (1986)}

\section{General comparison}

In order to re-examine the validity of the separate predictions for daily ore production rates obtained by Taylor (1986), whose data came from the 70s and 80s, and by Long (2009), who used data up to 2008 , we

\begin{tabular}{|l|l|l|l|}
\hline $\begin{array}{c}\text { Expected } \\
\text { reserves } \\
\text { (in mio t) }\end{array}$ & $\begin{array}{c}\text { Lifetime } \\
\text { according to } \\
\text { Long's formu- } \\
\text { la for capacity } \\
(10)\end{array}$ & $\quad / / C F=b_{n_{u g}}$ & $\begin{array}{c}\text { Interest rate } \mathbf{~} \\
\text { of the annuity } \\
\text { present value } \\
\text { factor } \boldsymbol{b}_{\boldsymbol{}_{u g}}\end{array}$ \\
\hline 0.5 & 3 & 1.9 & 26.8 \\
\hline 1.0 & 4 & 2.1 & 31.8 \\
\hline 5 & 8.5 & 2.7 & 33.9 \\
\hline 10 & 11.5 & 3.0 & 31.9 \\
\hline 25 & 17 & 3.6 & 27.3 \\
\hline 50 & 23.5 & 4.2 & 23.7 \\
\hline 100 & 32 & 5.0 & 19.9 \\
\hline 250 & 48 & 6.7 & 14.9 \\
\hline 350 & 55 & 7.5 & 13.3 \\
\hline 500 & 65 & 8.7 & 11.5 \\
\hline 700 & 75 & 10.2 & 9.8 \\
\hline 1,000 & 88 & 12.3 & 8.1 \\
\hline
\end{tabular}

Table 6. Changes in economics by using Long's instead of Taylor's capacities for underground mines.

Tabla 6. Cambios en la economía utilizando las capacidades de Long en lugar de las de Taylor para minas subterráneas. have tested these two relationships with data from mines that have been brought into production since 2012 or planned to be brought into production sometime in the future. The latter with current status as reserves development, feasibility or construction. The dataset comprises 243 copper, gold and lead-zinc-silver mines and projects, of which 179 are open-pit and block caving mines and projects (from now on only called "projects") and 64 underground projects (without block caving), with published capacity and reserves. The data were taken from S\&P Global Market Intelligence (Copyright $\subset$ 2018, S\&P Global Market Intelligence). As reserves are depleted over time and partially replaced by resources, it is difficult to get the "correct" reserves at the beginning of the productive phase of a mining project, which is needed to calculate the daily capacity of a mine. For this reason, we chose operating mines that have come into production since 2012 and preferentially took the tonnages of reserves, published for the year the production started (if available) or the latest available data. In some cases, the given reserves or the capacity taken from the S\&P database were changed on the basis of a direct crosscheck with actual information on the project. To compare the forecasted daily production of Taylor and Long with the installed capacity of existing projects, the ratios of the forecasted production of Taylor and Long respectively and existing projects were calculated. Ratios less than 1 indicate a larger capacity for the project than forecasted and all results above unity stand for higher forecasted production compared to the projects.

Taking all 243 projects, the average ratio of Taylor's forecast production to the recent projects is 0.73 clearly below the ratio of 1.03 of Long and greatly underestimating the installed/planned capacity (Table 7). Taylor's production forecasts range between a ratio of 0.70 for open-pit mines to underground operations with 0.82 . This difference is clearly larger than the fig-

\begin{tabular}{|l|l|l|l|}
\hline & Taylor & Long & $\mathbf{n}$ \\
\hline all projects & 0.73 & 1.03 & 243 \\
\hline Open Pit & 0.70 & 1.04 & 179 \\
\hline Underground & 0.82 & 0.99 & 64 \\
\hline
\end{tabular}

Table 7. Ratio of the predicted daily capacity of Taylor (1986) and Long (2009) compared to a sample of mines in production since 2012 and of projects under development. Comparison between underground and open-pit/block caving projects.

Tabla 7. Relación de la capacidad diaria prevista de Taylor (1986) y Long (2009) en comparación con una muestra de minas en producción desde 2012 y de proyectos en desarrollo. Comparación entre proyectos de minería subterránea y "a cielo abierto"/ "block caving". 


\begin{tabular}{|l|l|l|l|}
\hline \multicolumn{1}{|c|}{ Reserves [t] } & \multicolumn{1}{|c|}{ Taylor } & \multicolumn{1}{c|}{ Long } & \multicolumn{1}{c|}{ n } \\
\hline$<1.000 .000$ & 0.54 & 1.01 & 19 \\
\hline$<5.000 .000$ & 0.70 & 1.16 & 45 \\
\hline$<10.000 .000$ & 0.70 & 1.03 & 28 \\
\hline$<20.000 .000$ & 0.77 & 1.08 & 33 \\
\hline$<50.000 .000$ & 0.68 & 0.94 & 45 \\
\hline$<100.000 .000$ & 0.71 & 0.95 & 19 \\
\hline$<250.000 .000$ & 079 & 1.00 & 18 \\
\hline$<500.000 .000$ & 0.98 & 1.17 & 12 \\
\hline$>500.000 .000$ & 0.84 & 0.92 & 24 \\
\hline
\end{tabular}

Table 8. Ratio of the predicted daily capacity of Taylor (1986) and Long (2009) compared to mines in production since 2012 and projects in different development stages. Comparison for mines with different reserves.

Tabla 8. Relación de la capacidad diaria prevista con Taylor (1986) y Long (2009) en comparada con las minas en producción desde 2012 y los proyectos en diferentes etapas de desarrollo. Comparación de minas con diferentes reservas.

ures of Long of 1.04 for open pits and 0.99 for underground projects respectively. The different forecast capacities from both models is especially pronounced for small reserves (Table 8).

The bigger the reserves, the smaller the difference between the models (Table 8 and Fig. 8). Long's formula for open pit and block caving (equation 8):

$$
\text { tonnes }_{\text {day }}=c p_{\text {Long op }}=0.123 \times r e s_{\text {exp }}^{0.65}
$$

yield quite similar results to those derived from data presented here, especially for smaller reserves up to 50 Mio:

$$
\text { tonnes }_{d a y}=c p_{o p>2011}=0.084 \times r e s_{\exp }^{0.6727}
$$

The exponent 0.6727 lies just outside the $95 \%$ confidence interval given by Long (2009) for his exponent of 0.649 .

For underground mines Long (2009) introduced a formula different from the one used for open-pit mines (Eq. 9). This equation results in a higher production rate for reserves up to 10 Mio. $t$, compared to Taylor (1986) and lower production figures for projects larger than 10 Mio. t. The new equation

$$
\text { tonnes }_{d a y}=c p_{u g>2011}=0.2425 \times \operatorname{res}_{\mathrm{exp}}^{0.5827}
$$

for existing projects since 2012 gives results that lie between the capacities estimated by Taylor (1986) and Long (2009) for bigger underground reserves. The exponent 0.5827 lies inside the $95 \%$ confidence inter-

\section{Installed capacity of open pit and block caving projects vs. reserves}

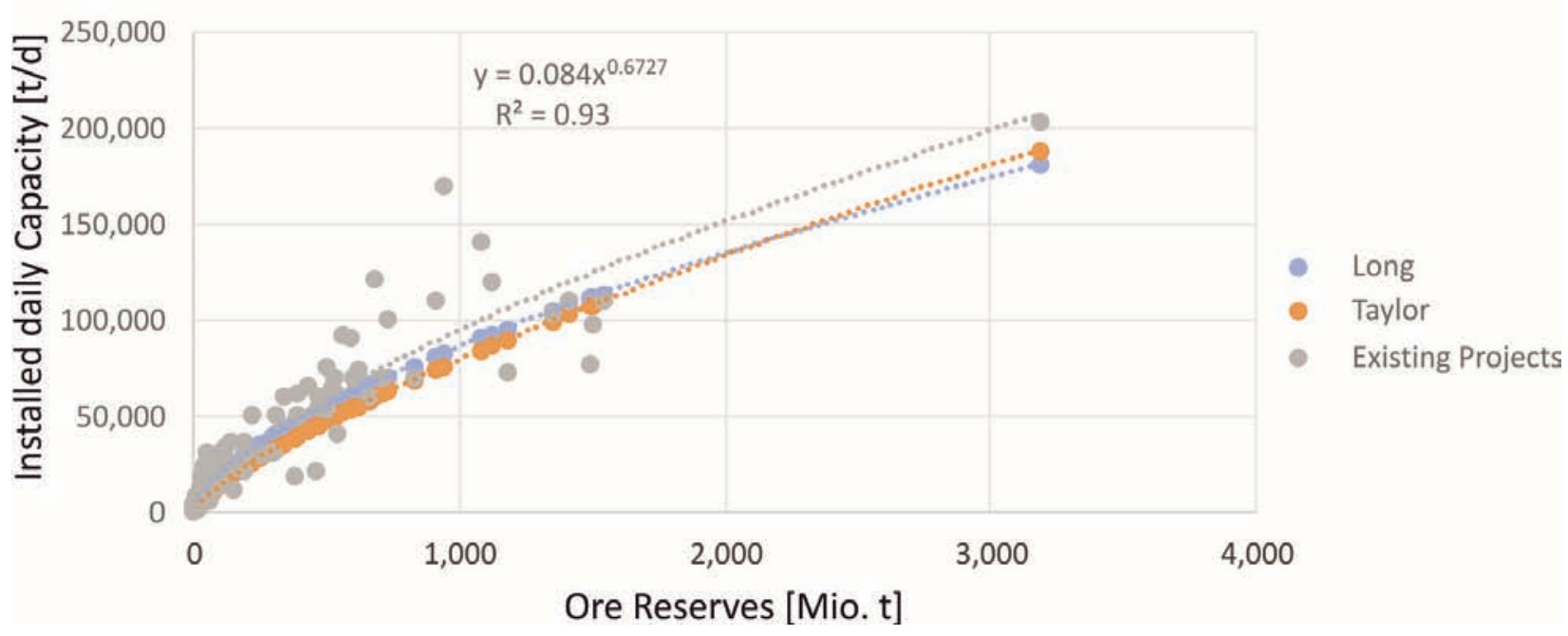

Figure 8. Comparison of the forecasted production of Long and Taylor with existing projects for open-pit and block caving mining projects. The dotted lines represent the forecasted capacities from Long (blue), Taylor (orange) and for existing mines and projects (black).

Figura 8. Comparación de la producción pronosticada según Long y Taylor con proyectos actuales de minería a cielo abierto y subterráneos de "block caving". Las líneas de puntos representan las capacidades pronosticadas según Long (azul), Taylor (naranja) y para minas y proyectos actuales (negro). 


\section{Installed capacity of underground projects vs. reserves}

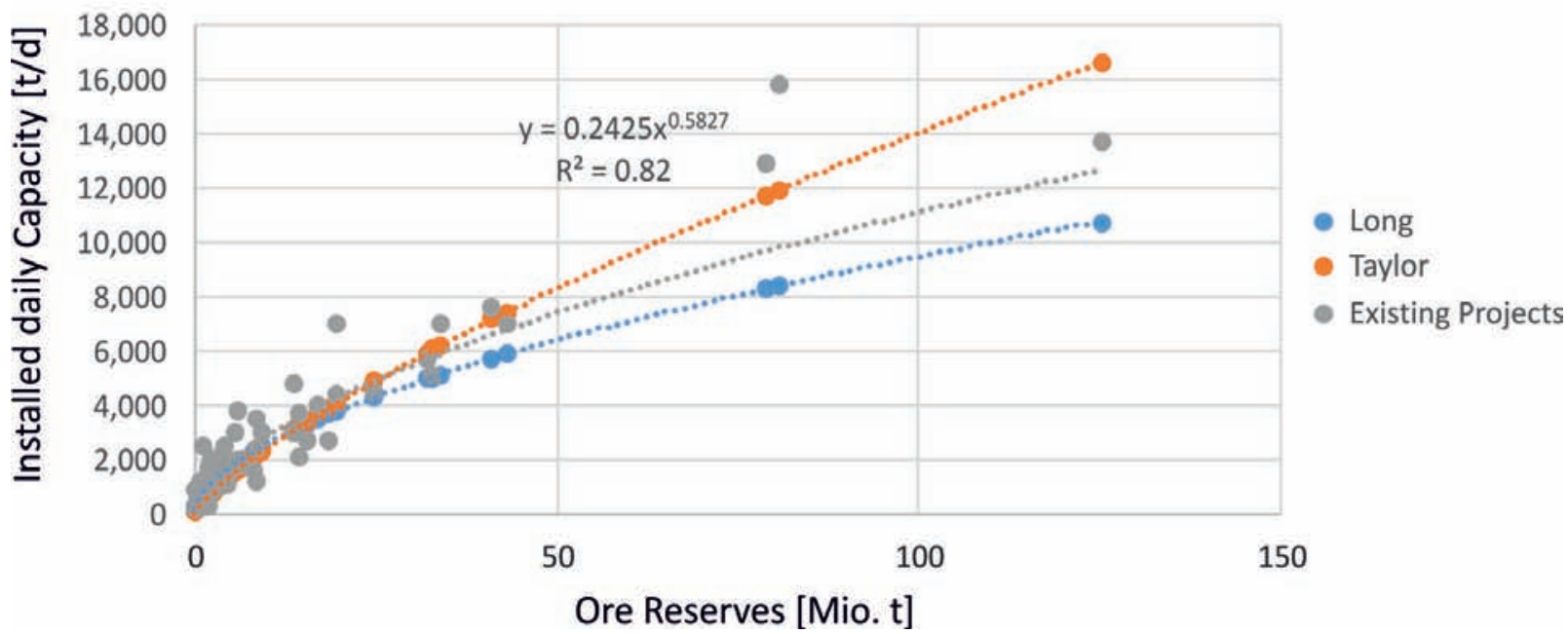

Figure 9. Comparison of the forecasted production of Long and Taylor with existing projects for underground mining projects. The dotted lines represent the forecasted capacities from Long (blue), Taylor (orange) and for existing mines and projects (black).

Figura 9. Comparación de la producción prevista de Long y Taylor con proyectos actuales de minería subterránea. Las líneas de puntos representan las capacidades pronosticadas según Long (azul), Taylor (naranja) y para minas y proyectos actuales (negro).

val given by Long (2009) for his exponent 0.563 . The plots of production forecasts of Taylor and our data intersect for reserves around 25 Mio. t (Fig. 9). For smaller reserves, the new equation gives higher production rates compared to Taylor (1986) and Long (2009).

\section{Comparison by commodities and countries}

As Table 9 shows there are similarities in the capacity ratios between gold and copper mines, compared to lead-zinc-silver mines. Taylor's model only fits data for underground copper mines $(n=9)$, whereas Long's model has a good fit for all copper and gold mines, but does not have a good fit for open-pit or underground mines of lead-zinc-silver.

There are also differences in capacities between countries as well. Table 10 includes only those countries with 5 or more projects in order to secure a minimum statistical sample and avoid becoming too prone to distortions by outliers. As the data of Long (2009) have a better fit compared to active projects than Taylor (1986), only his model will be tested here.

The formula of Long can only be applied to a limited extent on mining projects in Russia and China. Mining projects in these countries have a smaller installed capacity than predicted by Long (2009). The reason can probably be found in different resource estimations and reporting standards compared to those of western countries or countries with a large number of operations by western companies. (Such as Australia, for instance, where standards have been established by the Joint Ore Reserves Committee (JORC) code, which are also widely accepted internationally or Canada with the NI 43-101- code). Reported reserves in China and Russia are likely to include

\begin{tabular}{|l|l|l|l|}
\hline & \multicolumn{1}{|c|}{ Taylor } & \multicolumn{1}{c|}{ Long } & \multicolumn{1}{c|}{$\mathbf{n}$} \\
\hline Copper & & & $n$ \\
\hline total & 0.85 & 1.05 & 60 \\
\hline OP & 0.82 & 1.04 & 51 \\
\hline UG & 1.02 & 1.09 & 9 \\
\hline Gold & & & \\
\hline total & 0.68 & 1.03 & 154 \\
\hline OP & 0.64 & 1.03 & 120 \\
\hline UG & 0.82 & 1.04 & 34 \\
\hline Lead-zinc-silver & & & \\
\hline total & 0.74 & 0.98 & 29 \\
\hline OP & 0.75 & 1.24 & 8 \\
\hline UG & 0.74 & 0.87 & 21 \\
\hline
\end{tabular}

Table 9. Ratio of the predicted daily capacity of Taylor (1986) and Long (2009) for different commodities compared to the capacities since 2012.

Tabla 9. Relación de la capacidad diaria prevista por Taylor (1986) y Long (2009) para diferentes metales desde 2012. 
material that would be classified as resources by western standards, resulting in higher reported reserves. The calculation of the daily capacity would hence be based on a tonnage (reserve) that is too high, resulting in daily capacities that would be overestmated. But for actual mine planning, the operators in Russia and China probably only took the "real" reserves into account, resulting in a smaller calculated capacity with a better fit to the model of Long. Note also that the sample of mining projects since 2012 in these countries is relatively low (8 for China and 11 for Russia), although they do not seem to be influenced by outliers. In China there might have been some influence on capacity choices for non-economic reasons imposed by government authorities.

In contrast, the capacities are underestimated in Australia $(0.83 ; n=37)$ and Peru $(0.79 ; n=13)$. Larger capacities are usually installed where labour is cost intensive, as for example in fly in fly out projects, or where the risks (e.g. political stability, taxes, security) are high. Australian mining companies are regarded as ones, which operate at the forefront of technology. Another reason could be large projects, where resources are substantial, but have not yet been upgraded to reserves by infill drilling and the company may have installed additional capacity in expectation of converting some of these resources into reserves. This can be seen in Table 8 , where Long (2009) underestimates capacity for projects $>500$ Mio. t.

In some cases, a company might deem a project to have substantial potential for reserve growth (Cranstone 1988, Wagner 1999), although this may not be supported by tangible resources. From a geological point of view, there may be more to reserves and resources than meets the eye. An example is the Inmaculada project in Peru, where the installed capacity of $3850 \mathrm{t} / \mathrm{d}$ is twice as high as the forecast of Long (1900 t/d) would suggest and the company is still planning to increase ore processing capacity, without a reduction in the mine's life. This situation can only be ascertained by having a closer look into the details of the project. Unfortunately, for most projects pertinent information is not always disclosed to the public.

\section{Comparison by size of reserves}

The new formula (20) for the calculation of the daily tonnage of open-pit and block caving mining projects is very close to that introduced by Long (2009) up to reserves of around 50 Mio. t. For higher reserves we obtain slightly higher forecasted production capaci-

\begin{tabular}{|l|l|l|l|}
\hline \multicolumn{1}{|c|}{ Country } & \multicolumn{1}{c|}{ Taylor } & \multicolumn{1}{c|}{ Long } & \multicolumn{1}{c|}{ n } \\
\hline Argentina & 0.74 & 1.05 & 5 \\
\hline Australia & 0.55 & 0.83 & 37 \\
\hline Brazil & 0.72 & 1.06 & 10 \\
\hline Burkina Faso & 0.65 & 0.96 & 8 \\
\hline Chile & 0.74 & 0.89 & 5 \\
\hline China & 0.90 & 1.30 & 8 \\
\hline Canada & 0.84 & 1.03 & 33 \\
\hline Mali & 0.57 & 0.91 & 5 \\
\hline Mexico & 0.78 & 1.13 & 11 \\
\hline Peru & 0.64 & 0.79 & 13 \\
\hline Russia & 0.79 & 1.22 & 11 \\
\hline Turkey & 0.53 & 0.93 & 6 \\
\hline USA & 0.66 & 1.02 & 13 \\
\hline
\end{tabular}

Table 10. Ratio of forecasted production versus installed production for mining projects in different countries.

Tabla 10. Relación entre la producción prevista y la producción instalada para diversos proyectos mineros en diferentes países.

ties (Table 11). Generally, the fit of the curve is quite good $\left(R^{2}=0.93\right.$, Fig. 8). The differences between our data and Long (2009) are below $10 \%$ for most mining projects, which can be considered a small deviation. Due to the larger exponent, the formula of this study (20) and Taylor (1986) are converging for very big projects (almost the same for 3,000 Mio.t). As the majority of mining projects are much smaller than this, the big differences for projects with the smaller reserves range, outweigh this by far.

\begin{tabular}{|l|l|l|l|l|l|}
\hline $\begin{array}{c}\text { Reserves } \\
\text { Mio. t }\end{array}$ & Taylor & \multicolumn{1}{|c|}{ Long } & New & $\begin{array}{c}\text { New/ } \\
\text { Taylor }\end{array}$ & $\begin{array}{c}\text { New/ } \\
\text { Long }\end{array}$ \\
\hline 1 & 443 & 977 & 913 & 2.06 & 0.93 \\
\hline 10 & 2,490 & 4,364 & 4,297 & 1.73 & 0.98 \\
\hline 50 & 8,324 & 12,423 & 12,688 & 1.52 & 1.02 \\
\hline 100 & 14,000 & 19,494 & 20,225 & 1.44 & 1.04 \\
\hline 250 & 27,834 & 35,364 & 37,460 & 1.35 & 1.06 \\
\hline 500 & 46,812 & 55493 & 59,714 & 1.28 & 1.08 \\
\hline 1000 & 78,728 & 87,077 & 95,187 & 1.21 & 1.09 \\
\hline 2000 & 132,404 & 136,639 & 151,734 & 1.15 & 1.11 \\
\hline 3000 & 179,461 & 177,842 & 199,314 & 1.11 & 1.12 \\
\hline
\end{tabular}

Table 11. Comparison of the daily production rates of open pit and block caving mining projects taking the formulas of Taylor (1986), Long (2009) and this study (New).

Tabla 11. Comparación de las tasas de producción diarias de los proyectos de minería a cielo abierto y de "block caving" tomando las fórmulas de Taylor (1986), Long (2009) y este estudio (Nuevo). 


\begin{tabular}{|l|l|l|l|l|l|}
\hline $\begin{array}{c}\text { Reserves } \\
\text { Mio. t }\end{array}$ & Taylor & Long & New & $\begin{array}{c}\text { New/ } \\
\text { Taylor }\end{array}$ & $\begin{array}{c}\text { New/ } \\
\text { Long }\end{array}$ \\
\hline 1 & 443 & 680 & 760 & 1.72 & 1.12 \\
\hline 10 & 2,490 & 2,470 & 2,908 & 1.17 & 1.18 \\
\hline 50 & 8,324 & 6,084 & 7,429 & 0.89 & 1.22 \\
\hline 100 & 14,000 & 8,969 & 11,125 & 0.79 & 1.24 \\
\hline 250 & 27,834 & 14,983 & 18,975 & 0.68 & 1.27 \\
\hline
\end{tabular}

Table 12. Comparison of the daily production of underground mining projects taking the formulas of Taylor (1986), Long (2009) and this study (New).

Tabla 12. Comparación de la producción diaria de proyectos de minería subterránea tomando las fórmulas de Taylor (1986), Long (2009) y este estudio (Nuevo).

For underground projects, the differences between Long (2009) and the active projects presented here, are greater (Table 12). Our data predicts larger daily production capacities for all underground reserve sizes. The differences increase with increasing reserves. ForTaylor (1986) a comparison is difficult, as this author underestimates the production up to reserves of 25 Mio. $t$ and overestimates the production for reserves larger than 25 Mio. t.

\section{Conclusions}

For over 100 years, mineral commodity prices in real terms have not increased (Tilton et al., 2018). For this reason, mining companies are under considerable pressure to reduce the costs of their operations. One strategy is to increase capacity in order to benefit from economies of scale. This has been happening from 1980 onwards, especially in the 1990s (Crowson 2003). Taylor's Rule $(1977,1986)$ for estimating the relationship between reserves or resources and mine capacity used to be quite useful when estimates of capital and operating costs were needed for rule-ofthumb calculations during the exploration stage (Wellmer et al., 2008). However in 2009 Long re-evaluated Taylor's rule. Whereas Taylor (1977, 1986) lumped all mines together in one population, Long separated open-pit/block cave mines and underground mines. In this paper, we have examined the relative impact of using eitherTaylor's Rule or Long's formulas on project economics. These differences in estimated economic outcomes are significant. Although this study is a rule-of-thumb verification, it clearly illustrates the danger of using wrong capacities. The use of outdated capacity rules in the prefeasibility and exploration stage could easily lead to abandoning still attractive exploration targets and spending exploration funds on targets which are no longer attractive. Therefore, we recommend using Long's equations rather than Taylor's rule:

- For open-pit and block caving mines:

$$
\text { tonnes }_{\text {day }}=c p_{\text {Long op }}=0.123 \times \operatorname{res}_{\exp }^{0.65}
$$

- For underground mines:

$$
\text { tonnes }_{\text {day }}=c p_{\text {Long ug }}=0.297 \times r e s_{\exp }^{0.56}
$$

We tested these rules with actual data of mines younger than 2011 and found good agreement with Long's formula within an error of $10 \%$, certainly within a range of acceptable error at the exploration stage, making calculations with rules of thumb. In our test with data younger than 2011 the exponent for open pit mines lies just outside the 95\% confidence interval given by Long (2009), whereas the exponent for underground mines lies within the $95 \%$ confidence level.

The study clearly shows that the reserve-capacity relationship needs to be periodically re-examined on account of technological progress.

\section{Appendix 1}

\section{Derivation of the annuity present value formula}

To compare the effect of capacity changes we will use a modified IRR formula (3). We will assume a constant cash flow CF each year, meaning a cash flow before interest, taxes and royalty and compare it with the investment $I$. We start from equation (3).

$$
\sum_{n=1}^{N}\left(C F_{n} \times q_{j}^{-n}\right)=l
$$

If $C F$ is constant, then $C F x q_{j}^{-n}$ is a monotonically decreasing sequence and we can use the formula for the sum of such a sequence.

$$
\sum_{n=1}^{N}\left(C F \times q_{j}^{-n}\right)=C F \times \frac{q^{n}-1}{q^{n} \times(q-1)}=C F \times b_{n}
$$

In equation (18) and (19) $b_{n}$ is called the annuity present value factor (also called the discrete uniform 
present worth factor or series present worth factor) (Wellmer et al., 2008, p.133, p.226). Now we can combine equations (3) and (21) and write:

$$
\frac{l}{C F}=b_{n}
$$

For the annuity present value factor $b$ there are tables from which one can obtain, given an interest rate for a given number of years, the internal rate of return IRR (e.g. Wellmer et al., 2008, p. 226 and 227).

\section{Appendix 2}

Derivation of formula (12) to (15) for evaluating economic consequences of changing capacities from Taylor's rule to Long's relationships.

To compare the effect of capacity changes taking into account the counteracting effects of higher investment costs against lower operating costs with increasing capacity we examine the ratio of investment $I$ to cash flow $C F$, as given above in equation (10):

$$
\frac{I}{C F}
$$

We are not so much interested in the absolute value of the ratio $I / C F$, but how much this ratio changes when Long's relationships are set off against using Taylor's rule.

For investment I: we use the 0.6 rule for investment costs, given in equation (5) which is already a ratio. Now we can use equation (5) to compare the influence of Taylor's and Long's relationships on investment costs $l$ :

$$
\frac{I_{\text {Long }}}{I_{\text {Taylor }}}=\left(\frac{c p_{\text {Long }}}{c p_{\text {Taylor }}}\right)^{0.6}
$$

For the cash flow CF: we have to calculate the cash flows for the case of Taylor $C F_{\text {Taylor }}$ and of Long $C F_{\text {Long. }}$. The basic case will be the $C F_{\text {Taylor }}$ cash flow from which we derive the $C F_{\text {Long }}$ cash flow.

\section{Cash flow CF $_{\text {Taylor }}$}

We use a rule of thumb for profitable mines which states that the cut-off grade needed for operating costs $O C$ is about $50 \%$ of the average grade (Wellmer et al., 2008, p. 89; Wellmer and Scholz 2018), with the remaining $50 \%$ contributing to cash flow. As stated above, we assume no interest, taxes or royalties for our model calculations, thus the remaining $50 \%$ is our cash flow $\mathrm{CF} / \mathrm{t}$. We will take this as the standard case for Taylor's capacities and derive from it the annual cash flow $C F_{\text {Taylor. }}$ Therefore, we have to multiply the operating costs for the case of Taylor with the capacity and the annual working days. We take 350 working days as assumed in the studies of the US Geological Survey (Singer et al., 2000, Long et al., 2001):

$$
C F_{\text {Taylor }}=O C_{\text {Taylor }} \times c p_{\text {Taylor }} \times 350
$$

For our exercise we take the open-pit copper mines and the lead-zinc underground mines (equations 6 and 7) as examples for testing Taylor' and Long's relationships for the case of open-pit and underground mines. Therefore, for the case of openpit mines we insert equation (7) into equation (26):

$$
\begin{gathered}
C F_{\text {Taylor }}=2067 \times c p_{\text {Taylor }}^{-0.48} \times c p_{\text {Taylor }}^{1}= \\
2067 \times c p_{\text {Taylor }}^{0.52} \times 350=723450 \times c p_{\text {Taylor }}^{0.52}
\end{gathered}
$$

Cash flow CF $_{\text {Long }}$

Increasing the capacity for open-pit mines according to Long's relationship, we are reducing the operating costs (see equations 6 and 7), thereby increasing the cash flow $C F$, assuming constant grade and no changes in the cut-off grade. Therefore, we have to add the gain of cash flow to the cash flow of Taylor $C F_{\text {Taylor. }}$ For the cash flow $C F_{\text {Long op }}$ we now get:

$$
\begin{aligned}
& C F_{\text {Long }_{o p}}=\left(O C_{\text {Taylor }}+\left(O C_{\text {Taylor }}-O C_{\text {Long }_{o p}}\right)\right) \times C p_{\text {Long }} \\
& \times 350=\left(2 O C_{\text {Taylor }}-O C_{\text {Long }_{o p}}\right) 2067 \times C p_{\text {Long }_{o p}} \times 350
\end{aligned}
$$

Again, as in the case a) of the cash flow forTaylor's case $C F_{\text {Taylor, }}$ for open-pit mines we insert the equation (7) into equation (28)

$$
\begin{gathered}
C F_{\text {Long }}=2067 \times\left(2 c p_{\text {Taylor }}^{-0.48}-c p_{\text {Long }_{o p}}^{-0.48}\right) \times c p_{\text {Long }_{o p}} \times 350= \\
C F_{\text {Long }}=723450 \times\left(2 c p_{\text {Taylor }}^{-0.48}-c p_{\text {Long }_{o p}}^{-0.48}\right) \times c p_{\text {Long }_{o p}}
\end{gathered}
$$

For the cash flow ratio we now get, combining equation (27) and (29): 


$$
\begin{gathered}
\frac{C F_{\text {Long }_{o p}}}{C F_{\text {Taylor }}}=\frac{2067 \times\left(2 \times c p_{\text {Taylor }}^{-0.48}-c p_{\text {Long }_{o p}}^{-0.48}\right) \times C p_{\text {Long }_{o p}} \times 350}{2067 \times c p_{\text {Taylor }}^{0.52} \times 350}= \\
\quad \frac{C F_{\text {Long }_{o p}}}{C F_{\text {Taylor }}}=\frac{\left(2 \times c p_{\text {Taylor }}^{-0.48}-c p_{\text {Long }_{o p}}^{-0.48}\right) \times c p_{\text {Long }_{o p}}}{c p_{\text {Taylor }}^{0.52}}
\end{gathered}
$$

The equivalent for underground mines using the coefficients of equation (6) is:

$$
\frac{C F_{\text {Long }_{u g}}}{C F_{\text {Taylor }}}=\frac{\left(2 \times C p_{\text {Taylor }}^{-0.59}-c p_{\text {Long }_{u g}}^{-0.59}\right) \times C p_{\text {Long }_{u g}}}{c p_{\text {Taylor }}^{0.41}}
$$

\section{Acknowledgements}

The authors thank Bela Bognar and Keith R. Long for critically reading the paper and making numerous suggestions for improvements and Georg Wellmer for supplying the graphs in Figure 4 and Figure 5 a and $b$ and calculating the IRR.

\section{References}

BGR. 2017. Deutschland -Rohstoffsituation 2016, Hannover, $191 \mathrm{pp}$.

BGR. 2018. Databank

Cranstone, D.A. 1988. The Canadian Mineral Discovery Experience since World War II. In World Mineral Exploration. Trends and Economic Issues. Resources for the Future; Tilton, J.E., Eggert, R.G., Landsberg, H.H., Eds.; RFF-Press: Washington, DC, USA, pp. 283-329.

Crowson, P. 2003. Mine size and the structure of costs. Resources Policy 29 p. 15-36

EC (European commission) 2018. Towards a circular economy. https://ec.europa.eu/commission/priorities/jobsgrowth-and-investment/towards-circular-economy_en (accessed 20.2.18).

Glasson, M.J., Lehne, R.W., Wellmer, F.-W. 1988. Gold Exploration in the Callion Area, Eastern Goldfields, Western Australia-Journal Geochem. Exploration. 31, p. 1-19.

Gleeson, D. 2017. Mineral facts: Don't bank on it. Mining Journal, May 5-18, p. 21-23.

Götz, D. 2012. Personal communication 3.2.2012, conference "Ressources minérales: la vision du mineur", École des Mines, Paris.

Grosse, F. 2011. Quasi-Circular Growth: a Pragmatic Approach to Sustainability for Non-Renewable Material Resources. Sapiens 4, 2, p. 1-20.

Harvey, T. 2018. When is enough, enough? Preview February, p. 39-40.
Humphreys, D. 2001. Mining the knowledge-based economy. Minerals Energy 16, 3, p. 3-9.

Johnson, K. 1988. The Norseman gold deposits. Bicentennial Gold 88 Excursion Guidebook, University of Western Australia, Publication 14p. 114-121.

Joint Ore Reserves Committee. The JORC Code. 2017. Available online: http://www.jorc.org/aaa (accessed on 31 January 2017).

Lasserre, P. 1985. Capacity choice by mines. Canadian Journal Economics 18, p. 831-842.

Long, K.R. 2009. A Test and Re-Estimation of Taylor's Empirical Capacity-Reserve Relationship. Natural Resources Research, 18, p. 57-63.

Long, K.R. 2016. Taylor's Rule Revisited. In: The future for mining in a data-driven world, Society for Mining, Metallurgy and Exploration Annual Conference and Expo, Phoenix AZ 21.-24.2. 2016, Technical Program p. 206.

Long, K.R. 2018. Personal e-mail communication, 28.2.2018.

Long, K.R., Singer, D.A. 2001. A Simplified Economic Filter for Open-Pit Mining and Heap-Leach Recovery of Copper in the United States. US Geological Survey Open-File Report 01-218, 18 pp. https://pubs.usgs.gov/of/2001/ 0218/ pdf/of01-218.pdf (accessed 22.2.18).

McSpadden, G.M.; Schaap, W. 1984. Technical note-A test and comment on Taylor's rule of mine life. Proceedings Australasian Institute Mining and Metallurgy 298, p. 217-220.

Minerals Council of Australia 2014. Australias's Gold Industry-The Exploration Challenge. http://www.minerals.org.au/file_upload/files/resources/gold/The_exploration_challenge.pdf (accessed on 20.2.18).

Mount Isa Mines Ltd 2001. Company Global Metals, Mining, Steel conference, Dublin, Ireland.

Mular, A. L. 1978. Mineral Processing Equipment Costs and Preliminary Capital Cost Estimates. Canadian Institute Mining and Metallurgy, Special Volume 18.

National Instrument NI 43-101, available online http://web.cim.org/standards/documents/Block484_Doc1 11.pdf (accessed 29.4.18)

Nelles, M., Sachtleben Minerals GmbH \& Co. KG.2018. Personal communication, 23.3.18

Newman, A.M., Rubio, E., Caro, R., Weintraub, A., Eurek, K. A. 2010. Review of Operations Research in Mineral Planning. Interfaces 40, p. 222-245.

O'Hara, T. A. 1980. Quick guides to the evaluation of ore-bodies. Bulletin Canadian Institute Mining and Metallurgy 73(814), p. 87-99.

Podufal, P., formerly Sachtleben Bergbau GmbH 2018. Personal communication 24.3.18.

S\&P-Standard \& Poor's Market Intelligence 2018. Metals \& Mining Property Search.-Commercial Online-Database. New York, March 2018.

Sames, W., Wellmer. F.-W.1981. Exploration I: Nur wer wagt, gewinnt-Risiken, Strategien, Aufwand, Erfolg. Glückauf 117, 10, p. 580- 589. (translated for the English version of "Glückauf": Exploration, Part I: Nothing ventured, nothing gained. Glückauf + Translation 117, 10, p. 267-272).

Singer, D.A., Menzies, W. D., Long, K.R. 2000. A simplified economic filter for underground mining of massive sul- 
fide deposits. US Geological Survey Open-File Report 00-349, 20 pp. https://pubs.usgs.gov/of/2000/0349/ report.pdf (accessed 22.2.2018).

Steinbach, V., Wellmer, F.-W. 2010. Consumption and Use of Non-Renewable Mineral and Energy Raw Materials from an Economic Geology Point of View. Sustainability, 2 p. 1408-1430.

Taylor, H.K. 1977. Mine valuation and feasibility studies. In Mineral Industry Costs; Northwest Mining: Assoc.: Spokane, WA, USA, pp. 1-17.

Taylor, H.K. 1986. Rates of working of mines-A simple rule of thumb. Trans. Inst. Min. Metall. 95, A203-A204.

Tilton, J.E. , Crowson, P.C.F., DeYoung Jr, J.H., Eggert, R.G., Ericsson, M., Guzman, J.I., Humphreys, D., Lagos, G., Maxwell, P., Radetzki, M., Singer, D.A., Wellmer, F.-W. 2018. Public policy and future mineral supplies. Resources Policy. Article ID: https://doi10.1016/j.resourpol.2018.01.006.

Wagner, M. 1999. Ökonomische Bewertung von Explorationserfolgen über Erfahrungskurven. Ph.D. Thesis, Technical University, Berlin, Germany. Printed in
Geol. Jahrbuch SH 12, Schweizerbart (Stuttgart, Germany), 225p.

Wellmer, F.-W. 1979. Sind die Buntmetallagerstätten wirklich gewachsen? Erzmetall, 32, p. 24-31.

Wellmer, F.-W. 1981. Reserve/consumption ratios-How can they be interpreted? Bulletin Canadian Institute Mining and Metallurgy 74, p. 59-62.

Wellmer, F.-W. 2008. Reserves and resources of the geosphere, terms so often misunderstood. Is the life index of reserves of natural resources a guide to the future? Zeitschrift deutsche Gesellschaft für Geowissenschaften 159,4, p.575-590.

Wellmer, F.-W.; Dalheimer, M.; Wagner, M. 2008. Economic Evaluations in Exploration. Springer. Berlin/Heidelberg/ New York, 250 pp.

Wellmer, F.-W., Scholz, R.W. 2018. What is the Optimal and Sustainable Lifetime of a Mine? Sustainability 10, doi:10.3390/su10020480.

Wellmer, F.-W., Buchholz, P., Gutzmer, J., Hagelüken, C., Herzig, P., Littke, R., Thauer, R.K. 2018. Raw Materials for Future Energy Supply, Berlin/ Heidelberg/New York, in print.

Recibido: diciembre 2017

Revisado: febrero 2018

Aceptado: junio 2018

Publicado: marzo 2019 